\title{
PENGARUH LIKUIDITAS, HUTANG, INVESTASI, PROFITABILITAS, DAN PERTUMBUHAN PERUSAHAAN TERHADAP DIVIDEN PAYOUT RATIO PADA PERUSAHAAN MANUFAKTUR YANG TERDAFTAR DI BURSA EFEK INDONESIA TAHUN 2015-2018
}

\author{
Ni Kadek Ida Pratiwi ${ }^{1}$ \\ Putu Wenny Saitri ${ }^{2}$

\begin{abstract}
Fakuktas Ekonomi dan Bisnis Universitas Mahasaraswati Denpasar ${ }^{1,2}$
email: idapratiwi54@gmail.com
\end{abstract}

\begin{abstract}
Dividends are distributed to shareholders as earning after tax from company profit.The amount or percentage of profit taht a company will pay to shareholders as cash dividends is called the dividend payout ratio. The size of the dividend distributed by a company depends on the dividend plicy of the company, so it is necesarry to consider the comapny regarding the factors tha influence the dividend policy. The sample in this study was 34 manufacturing companies listed on the Indonesia Stock Exchange in 2015-2018.Determination of the sample using purposive sampling method. The analytical tool used is mutiple linear regression analysis. The result of the study using the t test showed that CR, DER, and investment had no significant effect on the dividend payout ratio, whereas $R O E$, had a positive ad significant effect on the dividend payout ratio. And company growth has negative effect on dividend payout ratio
\end{abstract}

Keywords: $\quad C R, D E R$, Investasi, ROE, Growth, Dividen Payout Ratio.

\section{PENDAHULUAN}

\section{Indonesia}

perkembangan yang cukup pesat. Banyak jenis usaha yang dikembangkan, mulai dari perusahaan jasa, perdagangan, manufaktur, dan lain-lain. Salah satu skala industri terbesar saat ini adalah Manufaktur. Perusahaan Manufaktur merupakan sector terbesar di Indonesia juga memiliki badan usaha terbanyak di Indonesia dan mampu memberikan dividen secara rata-rata dibandingkan dengan sector lainnya dan paling banyak membagikan dividen. Investasi di pasar modal merupakan hal yang menarik bagi para pemodal atau investor. Salah satu alasannya karena dividen yang ditetapkan oleh masing-masing perusahaan. Semua investor menanamkan modalnya di suatu perusahaan pasti berkeinginan mendapatkan pengembalian dalam bentuk dividen maupun capital gain dalam rangka meningkatkan kesejahteraannya. Penelitian ini berusaha menganalisa pengaruh likuiditas, hutang, investasi, profitabilitas, dan pertumbuhan perusahaan terhadap kebijakan dividen. Dalam penelitian ini, kebijakan dividen perusahaan diproksikan dengan dividen payout ratio. Beberapa faktor yang mempengaruhi kebijakan deviden antara lain: posisi likuiditas perusahaan, kebutuhan dana untuk membayar hutang, tingkat pertumbuhan perusahaan, dan pengawasan perusahaan. Dalam penelitian ini akan digunakan faktor 
yang mempengaruhi kebijakan dividen yaitu likuiditas, hutang yang diproksikan dengan Debt to Equity Ratio (DER), investasi, profitabilitas dan pertumbuhan perusahaan.

\section{Rumusan Masalah}

Berdasarkanlatar belakang diatas maka rumusan masalah pada penelitian ini adalah:

1) Apakah Likuiditas berpengaruh terhadap Dividen Payout Ratio pada perusahaan Manufaktur yang terdaftar di Bursa Efek Indonesia?

2) Apakah Hutang berpengaruh terhadap Dividen Payout Ratio pada perusahaan Manufaktur yang terdaftar di Bursa Efek Indonesia?

3) Apakah Investasi berpengaruh terhadap Dividen Payout Ratio pada perusahaan Manufaktur yang terdaftar di Bursa Efek Indonesia?

4) Apakah Profitabilitas berpengaruh terhadap Dividen Payout Ratio pada perusahaan Manufaktur yang terdaftar di Bursa Efek Indonesia?

5) Apakah Pertumbuhan Perusahaan berpengaruh terhadap Dividen Payout Ratio pada perusahaan Manufaktur yang terdaftar di Bursa Efek Indonesia?

\section{Tujuan Penelitian}

Berdasarkan rumusan masalah yang telah dikemukakan sebelumnya, maka tujuan penelitian ini adalah sebagai berikut:

1) Untuk menguji dan memperoleh bukti empiris pengaruh Likuiditas terhadap Dividen Payout Ratio pada Perusahaan Manufaktur yang terdaftar di Bursa Efek Indonesia.

2) Untuk menguji dan memperoleh bukti empiris pengaruh Hutang terhadap Dividen Payout Ratio pada Perusahaan Manufaktur yang terdaftar di Bursa Efek Indonesia
3) Untuk menguji dan memperoleh bukti empiris pengaruh Investasi terhadap Dividen Payout Ratio pada Perusahaan Manufaktur yang terdaftar di Bursa Efek Indonesia

4) Untuk menguji dan memperoleh bukti empiris pengaruh Profitabilitas terhadap Dividen Payout Ratio pada Perusahaan Manufaktur yang terdaftar di Bursa Efek Indonesia

5) Untuk menguji dan memperoleh bukti empiris pengaruh Pertumbuhan Perusahaan terhadap Dividen Payout Ratio pada Perusahaan Manufaktur yang terdaftar di Bursa Efek Indonesia

\section{TINJAUAN PUSTAKA Signaling Theory}

Signaling theory berarti suatu teori yang menyatakan bahwa investor akan menganggap besaran dividen yang mereka terima sebagai sinyal mengenai besaran manajemen atas laba di perusahaan tersebut, keberhasilan perusahaan membukukan profit, sehingga semakin besar dividen yang mereka terima, maka mereka akan menganggap bahwa pertumbuhan manajemen atas laba semakin meningkat. Pihak manajemen akan membayarkan dividen untuk memberikan sinyal mengenai.

\section{Pengertian Dividen}

Pengertia dividen menurut Rudianto (2012:290) adalah bagian laba usaha yang diperoleh perusahaan dan diberikan oleh perusahaan kepada pemegang sahamnya sebagai imbalan atas kesediaan mereka menanamkan hartanya dalam perusahaan. 


\section{Teori Kebijakan Dividen}

Kebijakan

dividen menyangkut masalah penggunaan laba yang menjadi hak para pemegang saham. Pada dasarnya, laba tersebut bisa dibagi sebagai dividen atau ditahan untuk diinvestasikan kembali. Dengan demikian pertanyaannya adalah kapan dividen akan dibagikan dan kapan akan ditahan dengan tetap memeperhatikan tujuan perusahaan yaitu peningkatan nilai perusahaan (Husnan; 2012; 297).

\section{Dividen Payout Ratio}

Dividen dibagikan kepada para pemegang saham sebagai earning after tax atau pendapatan setelah pajak dari laba perusahaan. Dan besaran atau persentase dari laba atau pendapatan yang akan dibayarkan oleh perusahaan kepada para pemegang saham sebagai dividen tunai disebut dividend payout ratio (Srinadi, 2014).

\section{Likuiditas}

Kasmir (2017:129) mendefinisikan bahwa likuiditas adalah kemampuan perusahaan untuk membayar hutang-hutangnya tepat pada waktunya. Dalam hal ini dititik beratkan pada kemampuan perusahaan untuk membayar hutang jangka pendek yang segera jatuh tempo pada waktunya.

\section{Hutang}

Hutang menurut Suprouse dan Monitzn dalam Ahmed Riahi dan
Belkaoui (2006:9) adalah kewajiban yang diakibatkan oleh transaksi dimasa lalu dan dimasa kini yang harus diselesaikan dikemudian hari.

\section{Investasi}

Investasi menurut Francis (2005:76) adalah suatu kegiatan penanaman modal pada aktiva-aktiva yang bersifat jangka panjang yang jangka waktu pembagiannya akan diperoleh lebih dari 5 tahun.

\section{Profitabilitas}

Profitabilitas merupakan kemampuan suatu perusahaan dalam mencari keuntungan dari penggunaan modalnya.

\section{Pertumbuhan Perusahaan}

Pertumbuhan perusahaan menurut Brigham dan Houston (2009) adalah perubahan (peningkatan atau penurunan) total aset yang dimiliki oleh perusahaan

\section{Kerangka Berfikir \\ Berdasarkan landasan teori atas permasalahan yang telah diungkapkan dalam penelitian ini, maka gambaran yang jelas penelitian ini menggunakan Dividen Payout Ratio sebagai variabel terikat (dependent variable), sedangkan Likuiditas, Hutang, Investasi, Profitabilitas, dan Pertumbuhan Perusahaan sebagai variabel bebas (independent variable).}




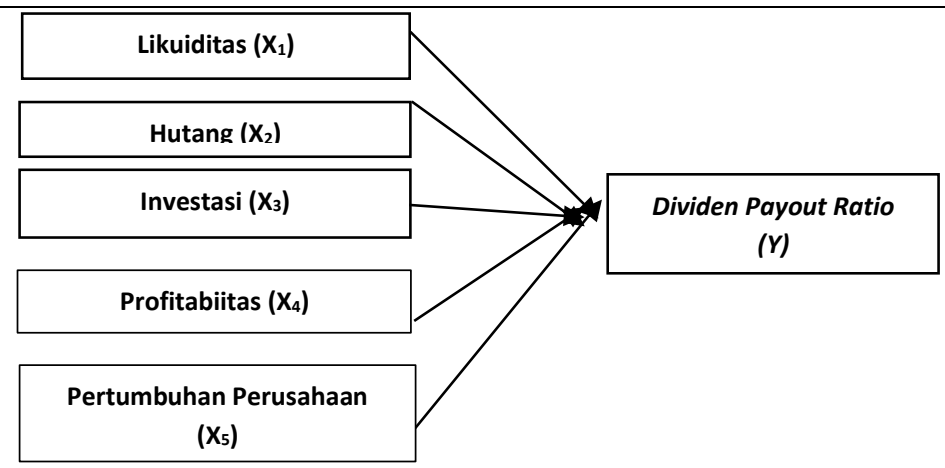

Sumber: Hasil Pemikiran Peneliti (2019)

Gambar 3.1

Kerangka Berpikir

Pengaruh Likuiditas, Hutang, Investasi, Profitabilitas, dan Pertumbuhan Perusahaan Terhadap Deviden Payout Ratio

Hipotesis

Pengaruh Likuiditas Terhadap

Dividen Payout Ratio Pada Perusahaan Manufaktur

Likuiditas perusahaan

merupakan pertimbangan utama dalam banyak keputusan dividen. Semakin tinggi likuiditas suatu perusahaan maka semakin rendah dividen yang dibagikan, karena perusahaan harus melunasi kewajibankewajiban jangka pendeknya, sehingga menyebabkan rendahnya dividen yang dibagikan. Berdasarkan keterangan diatas, maka dapat dirumuskan hipotesis sebagai berikut:

$\mathrm{H}_{1}$ : Likuiditas berpengaruh negatif terhadap Dividen Payout Ratio pada perusahaan manufaktur yang terdaftar di Bursa Efek Indonesia tahun 2015-2018.

\section{Pengaruh Hutang Terhadap Dividen Payout Ratio Pada Perusahaan Manufaktur}

Hutang dikatakan berpengaruh terhadap Dividen Payout Ratio karena yang digunakan untuk melunasi hutang ialah laba bersih perusahaan, dimana yang secara langsung akan mempengaruhi persentase dividen kas yang akan dibagikan kepada pemegang saham. Semakin tinggi hutang di sebuah perusahaan maka semakin rendah dividen yang dibagikan kepada investor, karena laba perusahaan akan digunakan untuk membayar hutang tersebut dan akan mengurangi dividen. Berdasarkan uraian diatas, maka dapat dirumuskan hipotesis sebagai berikut:

$\mathrm{H}_{2}$ : Hutang berpengaruh negatif terhadap Dividen Payout Ratio pada perusahaan manufaktur yang terdaftar di Bursa Efek Indonesia tahun 2015-2018.

\section{Pengaruh Investasi Terhadap Dividen Payout Ratio Pada Perusahaan Manufaktur \\ Hubungan Investasi dengan dividen payout ratio ialah jika suatu perusahaan melakukan investasi tentu adanya kas keluar dimana hal tersebut akan mengurangi dividen yang akan dibagikan kepada para pemegang saham. Semakin tinggi investasi suatu perusahaan maka semakin rendah dividen yang dibagikan.}


Berdasarkan uraian diatas, maka dapat dirumuskan hipotesis sebagai berikut:

$\mathrm{H}_{3}$ : Investasi berpengaruh negatif terhadap Dividen Payout Ratio pada perusahaan manufaktur yang terdaftar di Bursa Efek Indonesia pada tahun 2015-2018

\section{Pengaruh Profitabilitas Terhadap Dividen Payout Ratio Pada Perusahaan Manufaktur}

Profitabilitas merupakan kemampuan dan efektifitas penggunaan asset perusahaan dalam memperoleh laba selama periode tertentu.

Berdasarkan uraian diatas maka dapat dirumuskan hipotesis sebagai berikut:

$\mathrm{H}_{4}$ : Profitabilitas berpengaruh positif terhadap Dividen Payout Ratio pada perusahaan keuangan yang terdaftardi Bursa Efek Indonesia tahun 2015-2018

\section{Pengaruh Pertumbuhan Perusahaan Terhadap Dividen Payout Ratio Pada Perusahaan Manufaktur \\ Pertumbuhan perusahaan} adalah kemampuan perusahaan untuk meningkatkan nilai aset perusahaan dari waktu ke waktu. Makin cepat tingkat pertumbuhan suatu perusahaan, makin besar kebutuhan dana untuk waktu mendatang untuk membiayai pertumbuhannya. Berdasarkan uraian diatas, maka dapat dirumuskan hipotesis sebagai berikut.

$\mathrm{H}_{5}$ : Growth berpengaruh negative terhadap dividend payout ratio pada perusahaan manufaktur yang terdaftar di bursa efek Indonesia tahun 2015-2018.

\section{METODE PENELITIAN}

Obyek penelitian ini adalah data laporan keuangan perusahaan manufaktur di BEI periode 2015-2018. Variabel terikat dalam penelitian ini adalah Dividen Payout Ratio (Y). Dan variabel bebasnya adalah; $\mathrm{X}_{1}=$ Likuiditas, $X_{2}=$ Hutang, $X_{3}=$ Investasi, $\mathrm{X}_{4}=$ Profitabilitas, $\mathrm{X}_{5}=$ Pertumbuhan Perusahaan.

Populasi yang digunakan dalam penelitian ini adalah seluruh perusahaan manufaktur yang terdaftar di Bursa Efek Indonesia. Berdasarkan Indonesian Capital Market Directory (ICMD). Jumlah populasi dalam penelitian ini adalah 168 Perusahaan. Pemilihan sampel pada penlitian ini mengunakan metode purposive sampling, kriteria yang digunakan ialah Jumlah Perusahaan Manufaktur yang terdaftar BEI tahun 2015-2018, Perusahaan Manufaktur yang terdaftar berturut-turut di Bursa Efek Indonesia Tahun 2015-2018, Perusahaan Manufaktur yang menerbitkan laporan keuangan berturut-turut tahun 20152018, Perusahaan Manufaktur yang membagikan Deviden pada tahun 2015-2018, Perusahaan Manufaktur yang memperoleh laba pada tahun 2015-2018, karena perusahaan manufaktur yang rugi tidak bisa membagikan dividen, Perusahaan Manufaktur yang menggunakan satuan rupiah pada tahun 2015-2018. Dari kriteria tersebut diperoleh sampel sebesar 34 perusahaan.

Metode pengambilan data yang digunakan adalah metode dokumentasi.Data-data yang diperoleh akan diolah menggunakan SPSS dengan menggunakan alat statistik regresi linear berganda dengan satu variabel terikat (Y) dan lima variabel bebas $\left(\mathrm{X}_{1-5}\right)$.

\section{Analisis Statistik Deskriptif}

merupakan statistik yang menggambarkan atau mendeskriptifkan data menjadi 
sebuah informasi yang lebih jelas dan mudah dipahami (Ghozali, 2016:19).

2. Analisis

\section{Berganda}

Regresi Linier

Analisis regresi dilakukan untuk mengetahui seberapa besar hubungan antara variabel independen dengan variabel dependen.

3. Uji Asumsi Klasik

Uji asumsi klasik dilakukan dalam penelitian ini untuk menguji apakah data memenuhi asumsi klasik. Hal ini menghindari terjadinya estimasi yang bias. Salah satu syarat untuk bisa menggunakan uji regresi adalah terpenuhinya uji asumsi klasik. Adapun uji asumsi klasik dalam penelitian ini adalah:
a. Uji Normalitas
b. Uji Multikolinearitas
c. Uji Autokorelasi
d. Uji Heteroskedastisitas

\section{Uji Kelayakan Model}

Ketetapan dari fungsi sampel dalam menaksirkan nilai actual dapat diukur melalui uji kelayakan model. Secara statistic diukur dari nilai koefisien determinasi (adjusted $\mathrm{R}^{2}$ ), uji $\mathrm{f}$, dan uji $\mathrm{t}$ (Ghozali, 2016).

a. Koefisien Determinasi $\left(\mathrm{R}^{2}\right)$

b. Uji Statistik F

c. Uji Statistik t

\section{HASIL DAN PEMBAHASAN Analisis Statistik Deskriftip}

Analisis statistik deskriptif digunakan dengan tujuan untuk memberikan gambaran atau deskripsi mengenai suatu data yang dilihat dari nilai rata-rata (mean), standar deviasi (standard devia-tion), dan maksimumminimum.
Berdasarkan hasil analisis
statistik deskriptif data yang ditunjukkan pada Tabel 5.1 didapat hasil bahwa sampel yang berjumlah 136 dengan penjabaran sebagai berikut, Likuiditas (CR) memiliki nilai minimal 58,42. Nilai maksimal sebesar 1516,46 dan rata - rata sebesar 290,0896 dengan standar deviasi sebesar 236,39115, Hutang (DER) memiliki nilai minimal 0,08 . Nilai maksimal sebesar 16,02 dan rata - rata sebesar 0,8927 dengan standar deviasi sebesar 1,51979, Investasi (INV) memiliki nilai minimal 0,08 .

Nilai maksimal sebesar 1373,67 dan rata - rata sebesar 21,1131 dengan standar deviasi sebesar 116,95284, Profitabilitas (ROE) memiliki nilai minimal 0,18 . Nilai maksimal sebesar 135,85 dan rata rata sebesar 19,2329 dengan standar deviasi sebesar 26,01145, Pertumbuhan Perusahaan (GROWTH) memiliki nilai minimal $-99,89$. Nilai maksimal sebesar 103,05 dan rata rata sebesar 10,7381 dengan standar deviasi sebesar 18,89530, Dividen Payout Ratio (DPR) memiliki nilai minimal 0,16. Nilai maksimal sebesar 413,54 dan rata - rata sebesar 51,1828 dengan standar deviasi sebesar 53,75254 .

\section{Hasil Uji Normalitas}

1) Uji Normalitas

Dalam penelitian ini, untuk mendeteksi normalitas data dapat dilakukan dengan uji statistik Kolmogrov Smirnov. Ressidual berdistribusi normal jika memiliki nilai signifikansi $>0,05$. Hasil uji normalitas dapat dilihat pada Tabel 5.2 berikut ini: 


\title{
Tabel 5.1
}

\section{Hasil Uji Normalitas}

\begin{tabular}{|ll|r|}
\hline \multicolumn{2}{|c|}{ One-Sample Kolmogorov-Smirnov Test } \\
\hline N & $\begin{array}{r}\text { Unstandardiz } \\
\text { ed Residual }\end{array}$ \\
Normal Parameters ${ }^{\mathrm{a}, \mathrm{b}}$ & Mean & 136 \\
& Std. Deviation & .0000000 \\
Most Extreme & Absolute & 51.38842582 \\
Differences & Positive & .207 \\
& Negative & .207 \\
Kolmogorov-Smirnov Z & -.164 \\
Asymp. Sig. (2-tailed) & 1.248 \\
\hline \multicolumn{2}{|c|}{ a. Test distribution is Normal. } \\
b. Calculated from data.
\end{tabular}

Sumber: Lampiran 4, Data sekunder diolah, 2019

\section{2) Uji Multikolinearitas}

Multikolinearitas dapat di deteksi dengan bersaran Variance Inflation Factor (VIF) dan Tolerance. Jika VIF $<10$ dan Tolerance $>0.10$, maka varia-bel tersebut tidak mempunyai masalah multikolinearitas dengan variabel bebas lainnya.

\begin{abstract}
3) Uji Autokorelasi
Pada penelitian ini menggunakan uji autokorelasi bertujuan untuk menguji apakah model regresi ada korelasi atau pengaruh antara kesalahan pengganggu pada periode $\mathrm{t}$ dengan kesalahaan pengganggu pada periode t-1 (sebelumnya). Deteksi autokorelasi dilakukan dengan uji Durbin Watson yaitu $\mathrm{dU}<\mathrm{dW}<(4-\mathrm{dU})$ maka tidak terjadi autokolerasi.
\end{abstract}

Tabel 5.4

Hasil Uji Autokorelasi

Model Summary
\begin{tabular}{|l|r|r|r|r|c|}
\hline Model & R & R Square & $\begin{array}{l}\text { Adjusted } \\
\text { R Square }\end{array}$ & $\begin{array}{c}\text { Std. Error of } \\
\text { the Estimate }\end{array}$ & $\begin{array}{c}\text { Durbin- } \\
\text { Watson }\end{array}$ \\
\hline 1 & $.293^{\mathrm{a}}$ & .086 & .051 & 52.36734 & 1.891 \\
\hline
\end{tabular}
a. Predictors: (Constant), GROW, ROE, DER, CR, INV
b. Dependent Variable: DPR

Sumber: Lampiran 4, Data sekunder diolah, 2019

\section{4) Uji Heteroskedastisitas}

Heteroskedastisitas bertujuan untuk menguji apakah sebuah model regresi terjadi ketidaksamaan varians dari residual satu pengamatan ke pengamatan lainnya. Jika signifikansi masing - masing variabel bebas $>0,05$ maka dapat dikatakan tidak terjadi heteroskedastisitas. Tabel 5.5 menyajikan hasil uji heteroskedastisitas penelitian sebagai berikut : 
Tabel 5.5

Hasil Uji Heteroskedastisitas

\begin{tabular}{|c|c|c|c|c|c|c|}
\hline \multicolumn{7}{|c|}{ Coefficients $^{\mathrm{a}}$} \\
\hline \multirow[b]{2}{*}{ Mod } & & \multicolumn{2}{|c|}{$\begin{array}{c}\text { Unstandardized } \\
\text { Coefficients }\end{array}$} & \multirow{2}{*}{$\begin{array}{c}\text { Standardized } \\
\text { Coefficients } \\
\text { Beta }\end{array}$} & \multirow[b]{2}{*}{$t$} & \multirow[b]{2}{*}{ Sig. } \\
\hline & & $\mathrm{B}$ & Std. Error & & & \\
\hline \multirow[t]{6}{*}{1} & (Constant) & 39.271 & 7.936 & & 4.948 & .000 \\
\hline & $\mathrm{CR}$ & -.004 & .016 & -.024 & -.279 & .781 \\
\hline & DER & -2.008 & 2.479 & -.071 & -.810 & .419 \\
\hline & INV & -.058 & .037 & -.157 & -1.578 & .117 \\
\hline & ROE & -.144 & .146 & -.087 & -.988 & .325 \\
\hline & GROW & -.423 & .229 & -.185 & -1.850 & .067 \\
\hline
\end{tabular}

a. Dependent Variable: ABRES

\section{Hasil Uji Analisis Regresi Linier Berganda}

Hasil dari analisis regresi linier berganda yang diperoleh dari pengolahan data menggunakan program SPSS dapat dilihat pada Tabel 5.6:

Tabel 5.6

\section{Hasil Analisis Regresi Linier Berganda}

\begin{tabular}{|c|c|c|c|c|c|c|c|c|}
\hline \multicolumn{9}{|c|}{ Coefficients $^{\mathrm{a}}$} \\
\hline \multirow[b]{2}{*}{ Mod } & & \multicolumn{2}{|c|}{$\begin{array}{c}\text { Unstandardized } \\
\text { Coefficients }\end{array}$} & \multirow{2}{*}{$\begin{array}{c}\text { Standardized } \\
\text { Coefficients }\end{array}$} & \multirow[b]{2}{*}{$t$} & \multirow[b]{2}{*}{ Sig. } & \multicolumn{2}{|c|}{ Collinearity Statistics } \\
\hline & & B & Std. Error & & & & Tolerance & VIF \\
\hline \multirow[t]{6}{*}{1} & (Constant) & 55.949 & 9.629 & & 5.810 & .000 & & \\
\hline & $\mathrm{CR}$ & -.008 & .019 & -.036 & -.425 & .672 & .965 & 1.037 \\
\hline & DER & -2.241 & 3.007 & -.063 & -.745 & .458 & .972 & 1.028 \\
\hline & INV & -.043 & .045 & -.095 & -.971 & .333 & .741 & 1.350 \\
\hline & ROE & .415 & .177 & .201 & 2.351 & .020 & .961 & 1.041 \\
\hline & GROW & -.693 & .278 & -.244 & -2.497 & .014 & .739 & 1.354 \\
\hline
\end{tabular}

Berdasarkan hasil analisis regresi seperti yang disajikan pada Tabel 5.6, maka dapat dibuat persamaan struktural sebagai berikut:

DPR = 55,949-0,008CR-2,241DER0,043INV+0,415ROE-0,693GROW

Berdasarkan persamaan regresi linier berganda tersebut dapat dijelaskan koefisien-koefisiennya sebagai berikut: Nilai konstanta sebesar 55,949 , artinya jika variable bebas bernilai 0 maka nilai dividen payout ratio (DPR) sebesar 55,949, Nilai koefisien variabel profitabilitas (ROE) bernilai positif 0,415 , artinya apabila profitabilitas (ROE) mengalami peningkatan satu satuan dengan asumsi variabel likuitditas (CR), hutang (DER), investasi (INV), dan pertumbuhan perusahaan (GROWTH) dianggap tetap maka dividen payout ratio (DPR) akan meningkat sebesar 0,415, Nilai koefisien variabel pertumbuhan perusahaan (GROWTH) bernilai negatif $-0,693$, artinya apabila pertumbuhan perusahaan (GROWTH) mengalami peningkatan satu satuan dengan asumsi variabel likuitditas (CR), hutang (DER), investasi (INV), dan profitabilitas (ROE), dan dianggap tetap maka dividen payout ratio (DPR) akan menurun sebesar 0,693. 


\section{Hasil Uji Kelayakan Model}

1) Uji Koefisien Derterminasi (R2)

Pada penelitian ini, koefisien determinasi yang digunakan adalah $R$ square yang sudah di sesuaikan atau adjusted R2 karena nilai adjusted R2 dapat naik atau turun apabila satu variabel independen di-tambahkan ke dalam model. Tabel 5.6 menunjukan hasil uji koefisien determinasi (R2) sebagai berikut :

Tabel 5.7

Hasil Uji Koefisien Determinasi

\begin{tabular}{|l|r|r|r|r|r|}
\hline Model Summary \\
\hline Model & $\mathrm{R}$ & R Square & $\begin{array}{c}\text { Adjusted } \\
\text { R Square }\end{array}$ & $\begin{array}{c}\text { Std. Error of } \\
\text { the Estimate }\end{array}$ & $\begin{array}{c}\text { Durbin- } \\
\text { Watson }\end{array}$ \\
\hline 1 & $.293^{\mathrm{a}}$ & .086 & .051 & 52.36734 & 1.891 \\
\hline
\end{tabular}
a. Predictors: (Constant), GROW, ROE, DER, CR, INV
b. Dependent Variable: DPR

Besarnya pengaruh variabel bebas terhadap variabel terikat yang ditunjukkan oleh nilai determinasi total (Adjused $R$ Square) sebesar 0,051 mempunyai arti bahwa sebesar $5,1 \%$ variasi dividen payout ratio (DPR) dipengaruhi oleh variasi likuitditas (CR), hutang (DER), investasi (INV), profitabilitas (ROE), dan pertumbuhan perusahaan (GROWTH), sedangkan sisanya sebesar 94,39\% dijelaskan oleh faktor lain yang tidak dimasukkan ke dalam model.

\section{2) Uji Simultan $F$}

Apabila tingkat signifikansi $\mathrm{F} \leq \alpha$ $=0,05$ maka hubungan antara variabel bebas adalah signifikan mempengaruhi kinerja keuangan sebagai variabel terikat, sebaliknya jika tingkat signifikansi $\mathrm{F}>\alpha=0,05$ maka hubungan antar variabel bebas adalah tidak signifikan mempengaruhi kinerja keuangan sebagai variabel terikat. Tabel 5.8 menyajika hasil uji $\mathrm{F}$ penelitian sebagai berikut:

Tabel 5.8

\section{Hasil Uji Statistik F}

\begin{tabular}{|ll|r|r|r|r|r|}
\multicolumn{7}{|c|}{ ANOVA $^{\text {b }}$} \\
Model & & $\begin{array}{c}\text { Sum of } \\
\text { Squares }\end{array}$ & df & Mean Square & F & Sig. \\
\hline 1 & Regression & 33556.309 & 5 & 6711.262 & 2.447 & $.037^{\mathrm{a}}$ \\
& Residual & 356504.0 & 130 & 2742.338 & & \\
& Total & 390060.3 & 135 & & & \\
\hline
\end{tabular}

a. Predictors: (Constant), GROW, ROE, DER, CR, INV

b. Dependent Variable: DPR

Berdasarkan Tabel 5.8 hasil uji signifikansi simultan (Uji $\mathrm{F}$ ) diperoleh nilai signifikansi $F$ sebesar 0,037. Nilai Signifikansi $0,037<0,05$ mengindikasikan bahwa likuitditas (CR), hutang (DER), investasi (INV), profitabilitas (ROE), dan pertumbuhan perusahaan (GROWTH) berpengaruh 
signifikan terhadap dividen payout ratio pada perusahaan manufaktur terdaftar di Bursa Efek Indonesia dan model layak digunakan atau uji goodness of fit models dapat diterima.

\section{3) Uji Statistik Parsial t}

Uji t bertujuan untuk mengetahui apakah tiap variabel independen ber-pengaruh signifikan terhadap variabel dependen. Level of signifikan $(\alpha)$ yang digunakan adalah 5 persen $(0,05)$. Apabila signifikan variabel bebas lebih besar dari $\alpha$, maka $\mathrm{H} 0$ ditolak dan Ha diterima. Sebaliknya apabila signifikan variabel bebas lebih kecil atau sama dengan $\alpha$, maka $\mathrm{H} 0$ diterima dan Ha ditolak. Tabel 5.9:

Tabel 5.9

Hasil Uji Statistik t

\begin{tabular}{|c|c|c|c|c|c|c|c|c|}
\hline \multicolumn{9}{|c|}{ Coefficients $^{\mathrm{a}}$} \\
\hline \multirow[b]{2}{*}{ Model } & & \multicolumn{2}{|c|}{$\begin{array}{c}\text { Unstandardized } \\
\text { Coefficients }\end{array}$} & \multirow{2}{*}{$\begin{array}{c}\begin{array}{c}\text { Standardized } \\
\text { Coefficients }\end{array} \\
\text { Beta }\end{array}$} & \multirow[b]{2}{*}{$t$} & \multirow[b]{2}{*}{ Sig. } & \multicolumn{2}{|c|}{ Collinearity Statistics } \\
\hline & & B & Std. Error & & & & Tolerance & VIF \\
\hline 1 & (Constant) & 55.949 & 9.629 & & 5.810 & .000 & & \\
\hline & $\mathrm{CR}$ & -.008 & .019 & -.036 & -.425 & .672 & .965 & 1.037 \\
\hline & DER & -2.241 & 3.007 & -.063 & -.745 & .458 & .972 & 1.028 \\
\hline & INV & -.043 & .045 & -.095 & -.971 & .333 & .741 & 1.350 \\
\hline & ROE & .415 & .177 & .201 & 2.351 & .020 & .961 & 1.041 \\
\hline & GROW & -.693 & .278 & -244 & -2.497 & .014 & .739 & 1.354 \\
\hline
\end{tabular}

1. Pengaruh Likuiditas Terhadap Dividen Payout Ratio

Berdasarkan Tabel 5.9

hasil uji t likuiditas terhadap Dividen Payout Ratio diperoleh nilai koefisien beta $-0,008$ bernilai negatif, nilai t hitung $-0,425$ dan nilai signifikansi sebesar 0,672 . Hasil ini mempunyai arti bahwa likuiditas tidak berpengaruh terhadap Deviden Payout Ratio. Nilai Signifikansi $0,672>0,05$ mengindikasikan bahwa $\mathrm{H}_{1}$ ditolak.

2. Pengaruh Hutang Terhadap Dividen Payout Ratio

Berdasarkan Tabel 5.9 hasil uji t hutang terhadap dividen payout ratio diperoleh nilai koefisien beta $-2,241$ bernilai negatif, nilai $\mathrm{t}$ hitung $-0,745$ dan nilai signifikansi sebesar 0,458 . Hasil ini mempunyai arti bahwa hutang tidak berpengaruh terhadap Deviden Payout. Nilai Signifikansi $0,458>0,05$ mengindikasikan bahwa $\mathrm{H}_{2}$ ditolak.

3. Pengaruh Investasi Terhadap Dividen Payout Ratio

Berdasarkan Tabel 5.9 hasil uji $\mathrm{t}$ investasi terhadap dividen payout ratio diperoleh nilai koefisien beta $-0,043$ bernilai negatif, nilai $\mathrm{t}$ hitung $-0,971$ dan nilai signifikansi sebesar 0,333 . Hasil ini mempunyai arti bahwa investasi tidak berpengaruh terhadap Deviden Payout Ratio. Nilai Signifikansi 0,333>0,05 mengindikasikan bahwa $\mathrm{H}_{3}$ ditolak.

\section{Pengaruh Profitabilitas} Terhadap Dividen Payout Ratio Berdasarkan Tabel 5.9 hasil uji t profitabilitas terhadap Dividen Payout Ratio diperoleh 
nilai koefisien beta 0,415 bernilai positif, nilai t hitung 2.351 dan nilai signifikansi sebesar 0,020 . Hasil ini mempunyai arti bahwa Profitabilitas berpengaruh positif terhadap Dividen Payout Ratio. Nilai Signifikansi $0,020<0,05$ mengindikasikan bahwa $\mathrm{H}_{4}$ diterima.

5. Pengaruh Pertumbuhan Perusahaan Terhadap Dividen Payout Ratio

Berdasarkan Tabel 5.9 hasil uji t pertumbuhan perusahaan terhadap dividen payout ratio diperoleh nilai koefisien beta 0,693 bernilai negatif, nilai $t$ hitung -2.497 dan nilai signifikansi sebesar 0,014. Hasil ini mempunyai arti bahwa Growth berpengaruh negatif terhadap dividend payout ratio. Nilai Signifikansi $0,014<0,05$ mengindikasikan bahwa $\mathrm{H}_{5}$ diterima.

\section{Pembahasan}

\section{Pengaruh Likuiditas Terhadap Dividen Payout Ratio}

Berdasarkan Tabel 5.9 hasil uji t likuiditas terhadap Dividen Payout Ratio diperoleh nilai koefisien beta 0,008 bernilai negatif, nilai t hitung 0,425 dan nilai signifikansi sebesar 0,672 . Hasil ini mempunyai arti bahwa likuiditas tidak berpengaruh terhadap Deviden Payout Ratio. Nilai Signifikansi $0,672>0,05$ mengindikasikan bahwa $\mathrm{H}_{1}$ ditolak. Likuiditas tidak mempengaruhi peningkatan maupun penurunan dari Dividen Payout Ratio. Hal ini disebabkan oleh investor melihat besar kecilnya dividen yang diterima dari nilai laba dan harga pasar saham yang dapat dihasilkan oleh perusahaan. Hasil penelitian ini sejalan dengan penelitian yang dilakukan oleh Kholila (2019), dan Ibrahim (2019) yang menyatakan bahwa likuiditas tidak berpengaruh terhadap dividen payout ratio,

\section{Pengaruh Hutang Terhadap Dividen Payout Ratio}

Berdasarkan Tabel 5.9 hasil uji t hutang terhadap dividen payout ratio diperoleh nilai koefisien beta $-2,241$ bernilai negatif, nilai t hitung $-0,745$ dan nilai signifikansi sebesar 0,458. Hasil ini mempunyai arti bahwa hutang tidak berpengaruh terhadap Deviden Payout Ratio. Nilai Signifikansi $0,458>0,05$ mengindikasikan bahwa $\mathrm{H}_{2}$ ditolak. Dengan kata lain hutang tidak mempengaruhi peningkatan maupun penurunan dari Dividen Payout Ratio pada perusahaan manufaktur yang terdaftar di Bursa Efek Indonesia. Karena dalam pembagian dividen ditentukan dari Rapat Umum Pemegang Saham (RUPS), jadi perusahaan akan membagikan dividen sesuai RUPS yang telah ditetapkan oleh perusahaan. Dimana kebijakan dividen yang ditentukan oleh perusahaan ialah kebijakan dividen yang stabil, yaitu jumlah pembayaran dividen sama dari tahun ke tahun.

\section{Pengaruh Investasi Terhadap Dividen Payout Ratio}

Berdasarkan Tabel 5.9 hasil uji $\mathrm{t}$ investasi terhadap dividen payout ratio diperoleh nilai koefisien beta 0,043 bernilai negatif, nilai t hitung 0,971 dan nilai signifikansi sebesar 0,333 . Hasil ini mempunyai arti bahwa investasi tidak berpengaruh terhadap Deviden Payout Ratio. Nilai Signifikansi $0,333>0,05$ mengindikasikan bahwa $\mathrm{H}_{3}$ ditolak. Investasi tidak mempengaruhi 
peningkatan maupun penurunan dari Dividen Payout Ratio dikarenakan besar atau kecilnya investasi tidak menjamin bahwa dividen yang harus dibagikan besar atau kecil pula, melainkan sebaliknya dividen yang harusnya dibagikan kepada investor digunakan untuk pembelian aktiva tetap, pembelian saham dan obligasi di Bursa Efek Indonesia dan digunakan untuk biaya ekspansi perusahaan.

Hasil penelitian dari Srinadi (2014) dan Warniti (2011) menyatakan bahwa Investasi tidak berpengaruh terhadap dividen payout ratio.

\section{Pengaruh Profitabilitas Terhadap Dividen Payout Ratio}

Berdasarkan Tabel 5.9 hasil uji t profitabilitas terhadap Dividen Payout Ratio diperoleh nilai koefisien beta 0,415 bernilai positif, nilai $t$ hitung 2.351 dan nilai signifikansi sebesar 0,020. Hasil ini mempunyai arti bahwa Profitabilitas berpengaruh positif terhadap Dividen Payout. Nilai Signifikansi $0,020<0,05$ mengindikasikan bahwa $\mathrm{H}_{4}$ diterima. Dengan kata lain semakin meningkat profitabilitas pada perusahaan manufaktur yang terdaftar di Bursa Efek Indonesia akan semakin meningkatkan dividen payout ratio pada perusahaan manufaktur yang terdaftar di Bursa Efek Indonesia, sebaliknya jika dividen payout ratio pada perusahaan manufaktur yang terdaftar di Bursa Efek Indonesia semakin menurun maka profitabilitas pada perusahaan manufaktur yang terdaftar di Bursa Efek Indonesia akan semakin menurun juga. Semakin besar profitabilitas perusahaan maka semakin besar pula laba yang diperoleh dan presentase pembayaran dividen semakin besar. Hasil penelitian dari Sulandep (2016),
Yuliantari (2019), Martini (2019), Astuti (2018), Febrianti (2018), menyatakan bahwa variabel profitabilitas berpengaruh positif terhadap kebijakan dividen.

\section{Pengaruh \\ Pertumbuhan Perusahaan Terhadap Dividen Payout Ratio}

Berdasarkan Tabel 5.9 hasil uji $\mathrm{t}$ pertumbuhan perusahaan terhadap dividen payout ratio diperoleh nilai koefisien beta $-0,693$ bernilai negatif, nilai $\mathrm{t}$ hitung -2.497 dan nilai signifikansi sebesar 0,014. Hasil ini mempunyai arti bahwa Growth berpengaruh negatif terhadap dividend payout ratio. Nilai Signifikansi 0,014 $<0,05$ mengindikasikan bahwa $\mathrm{H}_{5}$ diterima.Dengan kata lain semakin meningkat pertumbuhan perusahaan pada perusahaan akan semakin menurunkan dividen payout ratio, sebaliknya jika dividen payout ratio pada perusahaan manufaktur yang terdaftar di Bursa Efek Indonesia semakin menurun maka pertumbuhan perusahaan pada perusahaan manufaktur yang terdaftar di Bursa Efek Indonesia akan semakin meningkat. Pertumbuhan perusahaan adalah kemampuan perusahaan untuk meningkatkan nilai aset perusahaan dari waktu ke waktu. Perusahaan akan membayar dividen jika tidak memiliki kesempatan untuk investasi yang menguntungkan, sehingga dapat disimpulkan bahwa asset growth memiliki pengaruh terhadap dividend payout ratio. Hasil penelitian sebelumnya oleh Lopolusi (2013) menyatakan bahwa Growth berpengaruh negatif. Hal ini menjadi perhatian bagi para investor untuk memperhatikan faktor growth ini dalam mengambil keputusan investasinya karena apabila aset 
perusahaan meningkat maka kecenderungan untuk menurunkan dividen.

\section{SIMPULAN DAN SARAN Simpulan}

Berdasarkan hasil analisis penelitian dan hasil pembahasan pada bab sebelumnya maka simpulan dari penelitian ini adalah sebagai berikut:

1. Likuiditas tidak berpengaruh terhadap dividen payout ratio pada perusahaan manufaktur yang terdaftar di Bursa Efek Indonesia. Dengan kata lain likuiditas pada perusahaan manufaktur yang terdaftar di Bursa Efek Indonesia tidak berpengaruh terhadap penurunan maupun peningkatan dividen payout ratio pada perusahaan manufaktur yang terdaftar di Bursa Efek Indonesia.

2. Hutang tidak berpengaruh terhadap dividen payout ratio pada perusahaan manufaktur yang terdaftar di Bursa Efek Indonesia. Dengan kata lain hutang pada perusahaan manufaktur yang terdaftar di Bursa Efek Indonesia tidak berpengaruh terhadap penurunan maupun peningkatan dividen payout ratio pada perusahaan manufaktur yang terdaftar di Bursa Efek Indonesia.

3. Investasi tidak berpengaruh terhadap dividen payout ratio pada perusahaan manufaktur yang terdaftar di Bursa Efek Indonesia. Dengan kata lain Dengan kata lain investasi pada perusahaan manufaktur yang terdaftar di Bursa Efek Indonesia tidak berpengaruh terhadap penurunan maupun peningkatan dividen payout ratio pada perusahaan manufaktur yang terdaftar di Bursa Efek Indonesia
4. Profitabilitas berpengaruh positif terhadap dividen payout ratio pada perusahaan manufaktur yang terdaftar di Bursa Efek Indonesia. Dengan kata lain semakin meningkat profitabilitas pada perusahaan manufaktur yang terdaftar di Bursa Efek Indonesia akan semakin meningkatkan dividen payout ratio pada perusahaan manufaktur yang terdaftar di Bursa Efek Indonesia, sebaliknya jika deviden payout ratio pada perusahaan manufaktur yang terdaftar di Bursa Efek Indonesia semakin menurun maka profitabilitas perusahaan akan semakin menurun juga

5. Pertumbuhan perusahaan berpengaruh negatif terhadap dividen payout ratio pada perusahaan manufaktur yang terdaftar di Bursa Efek Indonesia. Dengan kata lain semakin meningkat pertumbuhan perusahaan pada perusahaan manufaktur yang terdaftar di Bursa Efek Indonesia akan semakin menurunkan dividen payout ratio pada perusahaan manufaktur yang terdaftar di Bursa Efek Indonesia, sebaliknya jika dividen payout ratio pada perusahaan manufaktur yang terdaftar di Bursa Efek Indonesia semakin menurun maka pertumbuhan perusahaan pada perusahaan manufaktur yang terdaftar di Bursa Efek Indonesia akan semakin meningkat.

\section{Saran}

Berdasarkan simpulan tersebut maka saran dari penelitian ini adalah sebagai berikut: 
1. Bagi Mahasiswa, Hasil penelitian ini dapat digunakan sebagai sumber ajar alternative untuk manambah materi terkait mata perkuliahan terkait.

2. Bagi perusahaan, disarankan agar meningkatkan kinerja keuangannya dalam menghasilkan laba, karena investor cenderung menyukai perusahaan yang kinerja keuangannya sehat serta dapat menghasilkan laba yang stabil dan cenderung meningkat.

3. Bagi Universitas, Hasil penelitian ini dapat digunakan sebagai rekomendasi sumber ajar atau bahan diskusi pada mata kuliah terkait dalam kegiatan perkuliahan.

4. Bagi Peneliti selanjutnya yang ingin meneliti lebih lanjut pengaruh likuiditas, profitabilitas, hutang,investasi, dan pertumbuhan perusahaan terhadap dividen payout ratio pada perusahaan manufaktur yang terdaftar di Bursa Efek Indonesia dapat dilakukan dengan menambah sampel perusahaan serta menambah data berdasarkan tahun guna mendapatkan hasil yang sesuai dengan kenyataan sebenarnya.

\section{DAFTAR PUSTAKA}

Astuti. 2018. Pengaruh Profitabilitas, Leverage, dan Likuiditas terhadap Kebijakan Dividen. Skripsi. Program Studi Akuntansi Fakultas Ekonomi Universitas Mahasaraswati, Denpasar.

Dewi, Ni Wayan Risna. 2017. Pengaruh Hutang, Investasi, Profitabilitas, dan Ukuran Perusahaan Terhadap Dividen Payout Ratio Pada Perusahaan
Perbankan Yang Terdaftar Di Bursa Efek Indonesia Data 2010-2015. Skirpsi. Program Studi Akuntansi Fakultas Ekonomi Universitas Hindu Indonesia, Denpasar.

Dewi, Ni Putu Kartika. 2016. Pengaruh Rasio Keuangan Terhadap Kebijakan Deviden Pada Perusahaan Sektor Keuangan Yang Terdaftar Di Bursa Efek Indonesia Tahun 2012-2014. Skripsi. Program Studi Akuntansi Fakultas Ekonomi Universitas Mahasaraswati, Denpasar.

Fahmi, Irham. 2012. Pengantar Pasar Modal. cetakan kedua . Bandung: Alfabeta

Febrianti, Ida Ayu Kartika. 2018. Pengaruh Investment Oppurtunity Set, Ukuran Perusahaan, Pertumbuhan Laba, Profitabilitas Dan Leverage Terhadap Kebijakan Deviden Perusahaan Perbankan Yang Terdaftar Di Bursa Efek Indonesia Tahun 2013-2015. Skripsi. Program Studi Akuntansi Fakultas Ekonomi Universitas Mahasaraswati, Denpasar.

Ghozali, Imam. 2016. Aplikasi Analisis Multiprivate dengan IBM Program SPSS 23. Semarang: BPFE Universitas Diponegoro.

Harahap, Sofyan Syafri. 2007. Analisis Kritis Atas Laporan Keuangan, edisi pertama, cetakan ketiga, Penerbit: Raja Grafindo Persada, Jakarta. 
Husnan, Suad dan Enny Pudjiastuti. 2012. Dasar-dasar Manajemen Keuangan. Buku Satu. Edisi Keenam, UPP STIM YKPN, Yogyakarta.

Jannati, Attina .2012. Pengaruh Profitabilitas, Leverage dan Growth Terhadap Kebijakan Deviden Pada Perusahaan Manufaktur Consumer Goods Industry yang Listing di Bursa Efek Indonesia. Skripsi Sarjana Ekonomi Jurusan Akuntansi Universitas Siliwangi.

Jogiyanto. 2012. Teori Portofolio dan Analisis Investasi: Edisi Ketujuh. Yogyakarta: BPFE Yogyakarta

Kamsir. 2017. Analisis Laporan Keuangan, PT. Raja Grafindo Persada, Jakarta.

Lopolusi, Ita. 2013. Analisis FaktorFaktor Yang Mempengaruhi Kebijakan Dividen Sektor Manufaktur Yang Terdaftar Di PT Bursa Efek Indonesia Periode 2007-2011, Jurnal Ilmiah Universitas Surabaya Vol.2 No.1.2013.

Martono, dan D. Agus Harjito. 2011. Manajemen Keuangan. Edisi Kedua, Ekonisia. Yogyakarta.

Martini. 2019. Pengaruh Free Cash Flow, Profitabilitas, Kepemilikan Manajerial, dan Kebijakan Hutang terhadap Kebijakan Dividen pada Perusahaan Manufaktur yang Terdaftar di Bursa Efek Indonesia Tahun 2014-2017.
Skripsi. Program Studi Akuntansi Fakultas Ekonomi Universitas Mahasaraswati, Denpasar.

Putra, Rafael Eka. 2013. Pengaruh Profitabilitas, Leverage, Growth, Dan Likuiditas Terhadap Kebijakan Dividen Pada Perusahaan Manufaktur Yang Terdaftar Di Bursa Efek Indonesia Periode 2009-2012. Skripsi. Program Studi Akuntansi Universitas Maritim Raja Ali Haji, Tanjung Pinang.

Riyanto, Bambang. 2001. Dasardasar Pembelanjaan Perusahaan. Edisi keempat, Yogyakarta: BPFG

Rudianto. 2012. Akuntansi Pengantar. Jakarta: Erlangga.

Sartono, Agus. 2001. Manajemen Keuangan Teori dan Aplikasi. Yogyakarta:BPEFYogyakarta.

Sulandep, Pande Nyoman Sri. 2016. Analisis FAktor-Faktor Yang Mempengaruhi Devidend Payout Ratio Pada Perusahaan Manufaktur Yang Terdaftar Di Bursa Efek Indonesia Periode 2012-2014.

Sari, Komang Ayu Novita dkk. 2015. Pengaruh Likuiditas, Leverage, Pertumbuhan Perusahaan, dan Profitabilitas terhadap Kebijakan Deviden pada Perusahaan Manufaktur di BEI, Jurnal Ilmiah Universitas Udayana Vol.4 No.10.2015. 
Journal of Applied Management and Accounting science ( J A M A S )

(Ni Kadek Ida Pratiwi, Putu Wenny Saitri 92 - 107)

Vol 1, No 2, Juli 2020

Yuliantari. 2019. Analisis Pengaruh

Profitabilitas dan Likuiditas

terhadap Kebijakan Dividen

pada Perusahaan Manufaktur

yang Terdaftar di Bursa Efek

Indonesia. Skripsi. Program

Studi Akuntansi Fakultas

Ekonomi Universitas

Mahasaraswati, Denpasar.

$\underline{\text { Www.idx.co.id }}$ 